Article

\title{
Photocatalytic Performance of Electrospun Silk Fibroin/ZnO Mats to Remove Pesticide Residues from Water under Natural Sunlight
}

\author{
Isabel Garrido ${ }^{1}$, Salvador Aznar-Cervantes ${ }^{2}$, Marina Aliste ${ }^{1}$, María J. Yáñez-Gascón ${ }^{3}$, \\ Nuria Vela ${ }^{3}$, José L. Cenis ${ }^{2}$, Simón Navarro ${ }^{4, *(D)}$ and José Fenoll ${ }^{1}$ \\ 1 Sustainability and Quality Group of Fruit and Vegetable Products, Murcia Institute of Agri-Food Research \\ and Development, C/ Mayor s/n. La Alberca, 30150 Murcia, Spain; isabel.garrido3@carm.es (I.G.); \\ marina.aliste@carm.es (M.A.); jose.fenoll@carm.es (J.F.) \\ 2 Biotechnology Group, Murcia Institute of Agri-Food Research and Development, C/ Mayor s/n. La Alberca, \\ 30150 Murcia, Spain; salvadord.aznar@carm.es (S.A.-C.); josel.cenis@carm.es (J.L.C.) \\ 3 Applied Technology Group to Environmental Health, Faculty of Health Science, Catholic University of \\ Murcia, Campus de Los Jerónimos, s/n. Guadalupe, 30107 Murcia, Spain; mjgascon@ucam.edu (M.J.Y.-G.); \\ nvela@ucam.edu (N.V.) \\ 4 Department of Agricultural Chemistry, Geology and Pedology, Faculty of Chemistry, University of Murcia, \\ Campus Universitario de Espinardo, 30100 Murcia, Spain \\ * Correspondence: snavarro@um.es
}

Received: 23 December 2019; Accepted: 10 January 2020; Published: 12 January 2020

\begin{abstract}
We have evaluated the efficiency of silk fibroin (SF) coated with $\mathrm{ZnO}$ nanoparticles in the photocatalytic disappearance of one acaricide (etoxazole) and three fungicides (difenoconazole, myclobutanil and penconazole) in water exposed to sunlight irradiation. Electrospun SF/ZnO mats were successfully synthesized by electrospinning technique and characterized by XRD, FE-SEM, XPS, XDS, FTIR, and BET. The influence of catalyst loading on the degradation kinetics of the different pesticides was examined in order to gain knowledge of maximum degradation efficiency. A significant increment in degradation rates was observed with the addition of $\mathrm{ZnO}$. SF mats with $25 \mathrm{mg}$ of $\mathrm{ZnO}$ were finally selected since no significant differences $(p<0.05)$ were detected when the loading was enlarged from 25 to $50 \mathrm{mg}$ for the majority of the compounds. In the experimental conditions, the half-lives ranged from $33 \mathrm{~min}$ to $93 \mathrm{~min}$ for etoxazole and myclobutanil, respectively. The comparison of SF materials coated with similar amount of $\mathrm{TiO}_{2}$ and $\mathrm{ZnO}$ showed that the later was slightly more efficient to remove pesticide residues. Hence, the use of electrospun $\mathrm{SF} / \mathrm{ZnO}$ nanostructures would provide an environmentally friendly approach with photocatalytic activity to be applied in the reclamation of water polluted by pesticides.
\end{abstract}

Keywords: electrospun silk fibroin/ZnO mats; photocatalytic characterization; pesticides; solar irradiation; water remediation

\section{Introduction}

Agricultural activity depends heavily on the use of pesticides with the consequent risks for humans and the environment. Many of them are endocrine disruptors (EDs), compounds that alter the function(s) of the endocrine system and consequently cause adverse health effects in an intact organism, or its progeny, or sub-populations [1]. Owing to the required use of pesticides in intensive agriculture, their residues have important effects on the quality of aquatic ecosystems and drinking water resources. Recent studies have pointed to the presence of different pesticides in environmental (surface-, ground-, and seawater), waste- and drinking waters [2]. For this reason, the European 
Water Framework Directive proposes a strategy to fight against water pollution. Therefore, to protect its citizens from dangerous effects, the European Union (EU) has set quality standards $\left(0.1 \mathrm{mg} \mathrm{L}^{-1}\right.$ for individual pesticides and $0.5 \mathrm{mg} \mathrm{L}^{-1}$ for the sum of all pesticides). However, many of them are biorecalcitrants and are not amendable to microbial degradation. Consequently, other more effective technologies such as advanced oxidation processes (AOPs) have been proposed in the past years.

The development of AOPs constitute a significant alternative to traditional technologies such as adsorption, chemical coagulation/flocculation, precipitation, membrane filtration, ion exchange, or biological degradation because they get the removal of organic pollutants by mineralization instead of transferring them from water to other medium. Therefore, the research of photochemical techniques based on the use of sunlight in order to catalyze the degradation of these toxic compounds toward innocuous derivatives is becoming an important field of research nowadays [3-5]. These technologies are considered an advantageous option for the treatment of pesticide-polluted water because their effectiveness has been verified for different types of pesticides during the last decade [6]. In this context, binary semiconductors (SCs) like $\mathrm{TiO}_{2}$ and $\mathrm{ZnO}$ have been extensively used as photocatalysts because of their chemical and optical properties and their use to remove pollutants is being increasingly explored by scientific community [7-12]. $\mathrm{ZnO}$ is an excellent n-type semiconductor oxide that possesses excellent electrical, mechanical, and optical properties, similar to $\mathrm{TiO}_{2}$ although the influence of the synthesis parameters on the properties of the $\mathrm{ZnO}$ nanopowders is very important to improve their photocatalytic activity [13].

Typically, $\mathrm{TiO}_{2}$ and $\mathrm{ZnO}$ have been used in slurry form making their removal from the treated water cumbersome. To avoid this problem, different immobilized materials have been tested. In order to minimize the inherent risks of the systemic use of these materials and their prevalence in the environment, many attempts have been carried out to incorporate them into three-dimensional supports. In this sense, $\mathrm{ZnO}$ nanoparticles have been combined with cellulose supports [14] or matrices of fibroin $[15,16]$, among others. On the other hand, $\mathrm{TiO}_{2}$ nanoparticles are also used for the removal of organic contaminants because of their activity and optimal electronic and optical behavior [17-20] and its insertion into 3D-matrices is being studied [10]. Some recent works expose the potential uses of materials combining $\mathrm{SF}$ and $\mathrm{TiO}_{2}$ in their composition. For example, Cai et al. [21] stated a new methodology to produce silk fibers with enhanced mechanical properties by means of the feeding of silkworms with nanoparticles of $\mathrm{TiO}_{2}$. Other authors have produced SF films [22] or porous scaffolds [23] containing them as biomaterials for tissue engineering, improving their mechanical and thermal properties. Fibrous mats of $\mathrm{SF} / \mathrm{TiO}_{2}$ has also been manufactured as potential wound dressings [24] or in the field of self-cleaning textiles [9].

Electrospinning is a technique used to make fibrous scaffolds with different applications such as catalysts, filtration, electronic set ups or tissue engineering [25-29]. Silk fibroin (SF) is a protein produced by the silkworm (Bombyx mori), and it has been widely employed to produce electrospun materials [30-32], because of their excellent properties in terms of biocompatibility and mechanical behavior [33]. The electrospinning of this versatile protein allows the functionalization of the materials produced with different molecules of great interest. For instance, different growing factors [25,34,35], polymeric blends [26], conductive polymers $[27,28,36]$, or even nanoparticles have been successfully included in the composition of electrospun SF-mats $[9,37]$ with variety of applications. However, as far as we know, electrospun SF meshes have never been studied or produced as photocatalyst for the elimination of pesticides in polluted water.

With this aim, we propose a new methodology for manufacturing electrospun SF materials incorporating $\mathrm{ZnO}$ into their fibrillary network $(\mathrm{SF} / \mathrm{ZnO})$, analyzing their ability to degrade etoxazole (diphenyl oxazoline) and difenoconazole, myclobutanil and penconazole (triazole compounds) in water, pesticides commonly used in agriculture, by means of sunlight. In addition to this, their mechanical properties, infrared spectra, and appearance, using scanning electron microscopy, are also described. Finally, the photocatalytic efficiency of electrospun SF materials prepared with $\mathrm{TiO}_{2}\left(\mathrm{SF} / \mathrm{TiO}_{2}\right)$ was also evaluated and compared with $\mathrm{SF} / \mathrm{ZnO}$ for the reclamation of pesticide-polluted water. 


\section{Results and Discussion}

2.1. X-ray Diffraction (XRD), Field Emission Scanning Electron Microscopy (FESEM), X-ray Photoelectron Spectroscopy (XPS), and Energy Dispersive X-ray Spectroscopy Analysis (XDS) Characterization

$\mathrm{SF} / \mathrm{TiO}_{2}$ and $\mathrm{SF} / \mathrm{ZnO}$ samples were characterized following the methodology described by Fenoll et al. [38]. The characterization of $\mathrm{SF} / \mathrm{TiO}_{2}$ samples was described in a previous paper [39]. In the case of SF/ZnO samples, the X-ray diffractograms are showed in Figure 1. The XRD of SF/ZnO exhibited the peaks attributed to zincite (hexagonal system). In accordance with the PDF2 database (International Centre for Diffraction Data), the pattern showed by the peaks is closely associated to JCPDS card no. 36-1451. The characteristic zincite peaks at $2 \theta$ diffraction angles of 32, 34, 36, 47, 57, 63, 66, 68, 69, 72, and $77 \cdot$ corresponding to the planes $100,002,101,102,110,103,200,212,201,004$, and 002 respectively, were clearly observed. Consequently, we considered that the surface coverage of electrospun SF materials prepared with $\mathrm{ZnO}$ was complete. Figure 2A shows the SEM images of SF/ZnO. It can be seen that a non-uniform $\mathrm{ZnO}$ layer around the SF and a cluster of aggregates of $\mathrm{ZnO}$ accumulated on the surface. In addition, it can be observed that the hexagonal structure corresponds to zincite as demonstrated by XRD. Concerning the elemental mapping of SF/ZnO (Figure 2C-F), the surface coverage of the SF with $\mathrm{ZnO}$ was almost complete. In addition, EDX analysis (Figure 2G) showed the presence of $\mathrm{Zn}$ with $\mathrm{C}$ in the sample supporting the elemental mapping and XPS data that $\mathrm{Zn}$ surface coverage was almost complete. The SEM image of the $\mathrm{TiO}_{2}$ coated SF also showed a cluster of aggregates of $\mathrm{TiO}_{2}$ deposited on the SF [39]. These clustered aggregates cannot be broken down into smaller particles by physical processing.

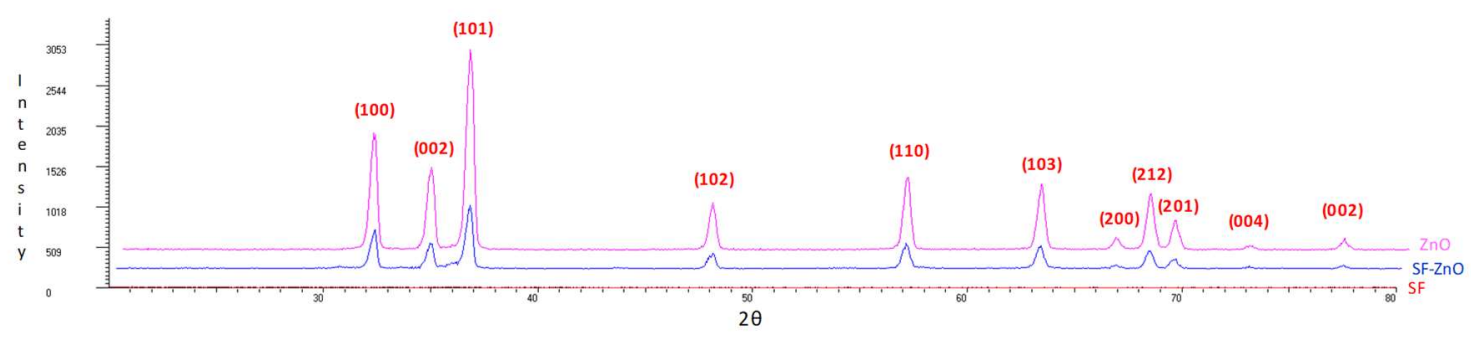

Figure 1. XRD patterns of $\mathrm{SF} / \mathrm{ZnO}, \mathrm{SF}$, and $\mathrm{ZnO}$.

The XPS survey spectra for SF/ZnO is exposed in Figure 3A. The Zn2p spectrum for SF/ZnO shows two peaks (1021.5 and $1044.7 \mathrm{eV}$ ) that are coincident to $\mathrm{Zn} 2 \mathrm{p}_{3 / 2}$ and $\mathrm{Zn} 2 \mathrm{p}_{1 / 2}$, while in pure $\mathrm{ZnO}$, these binding energies were 1021.1 and $1044.2 \mathrm{eV}$, respectively, according to Naumkin et al. 2012 [40]. Figure 3C illustrates the O1s spectra. O1s peaks show an asymmetric appearance that could be attributed to the existence of various oxygen bonds. The high intensity found in lower binding energy for O1s spectra suggests stronger $\mathrm{Zn}-\mathrm{O}$ bond in the $\mathrm{ZnO}$. The intermediary peak could be due to oxygen shortcomings of $\mathrm{ZnO}$. The higher binding energy peak may be attributed to the adsorption of hydroxyl species [41]. These results are in concordance with those obtained from the XRD pattern. The estimated value of surface area $\left(\mathrm{S}_{\mathrm{BET}}\right)$ for $\mathrm{SF} / \mathrm{ZnO}$ was $21 \mathrm{~m}^{2} \mathrm{~g}^{-1}$. 

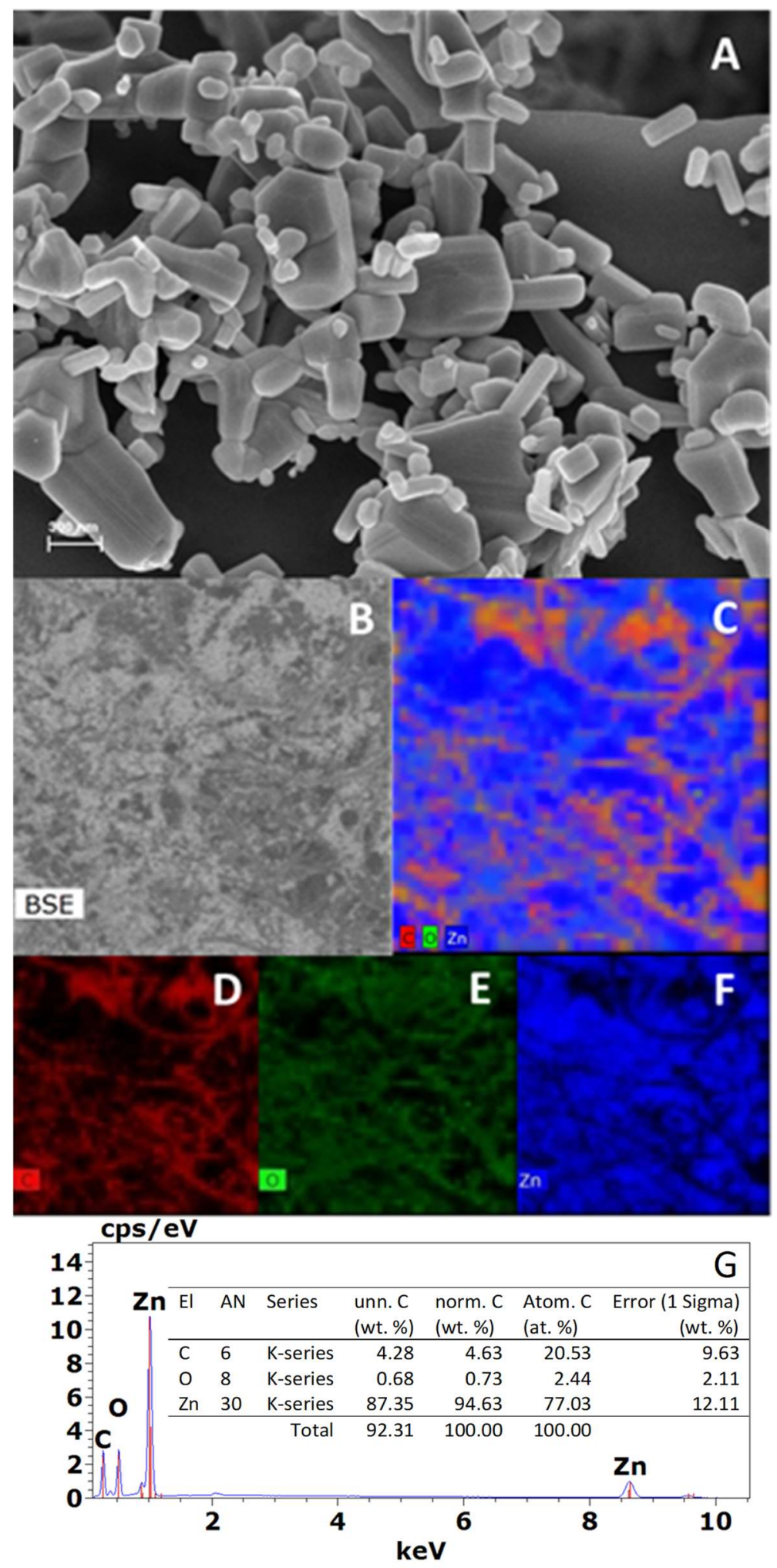

Figure 2. SEM image of SF/ZnO (A), back scattered electron (BSE) image (B), elemental mapping (C-F), and EDX data $(\mathbf{G})$ of a $\mathrm{SF} / \mathrm{ZnO}$ zone. 


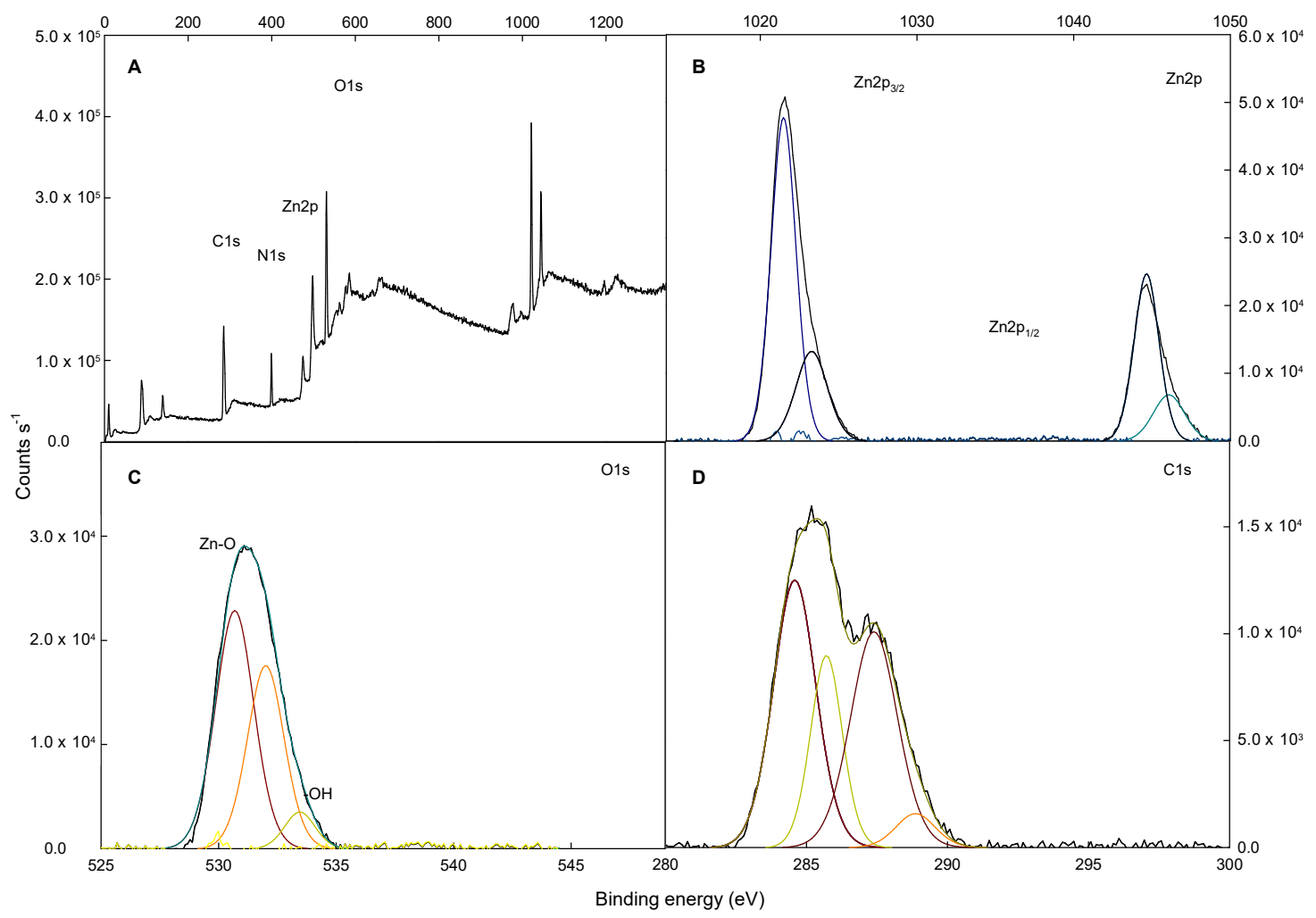

Figure 3. XPS spectra of SF/ZnO sample: (A) survey spectrum, (B-D) high-resolution binding energy spectra of Ti2p, O1s, and C1s, respectively.

\subsection{Attenuated Total Reflectance Fourier Transformed Infrared Spectroscopy (ATR-FTIR) Depiction}

$\mathrm{SF} / \mathrm{ZnO}$ mats revealed the typical peaks of fibroin corresponding to amide I $\left(1622 \mathrm{~cm}^{-1}\right)$, amide II $\left(1515 \mathrm{~cm}^{-1}\right)$, amide III $\left(1230 \mathrm{~cm}^{-1}\right)$, and amide IV $\left(1064 \mathrm{~cm}^{-1}\right)$, highlighted with blue arrows in Figure 4. These bands are described in the scientific literature for SF materials enriched in $\beta$-sheet conformation (non-soluble state in water) [42,43]. The non-presence of the peak at $1660 \mathrm{~cm}^{-1}$ also verified this fact [44].

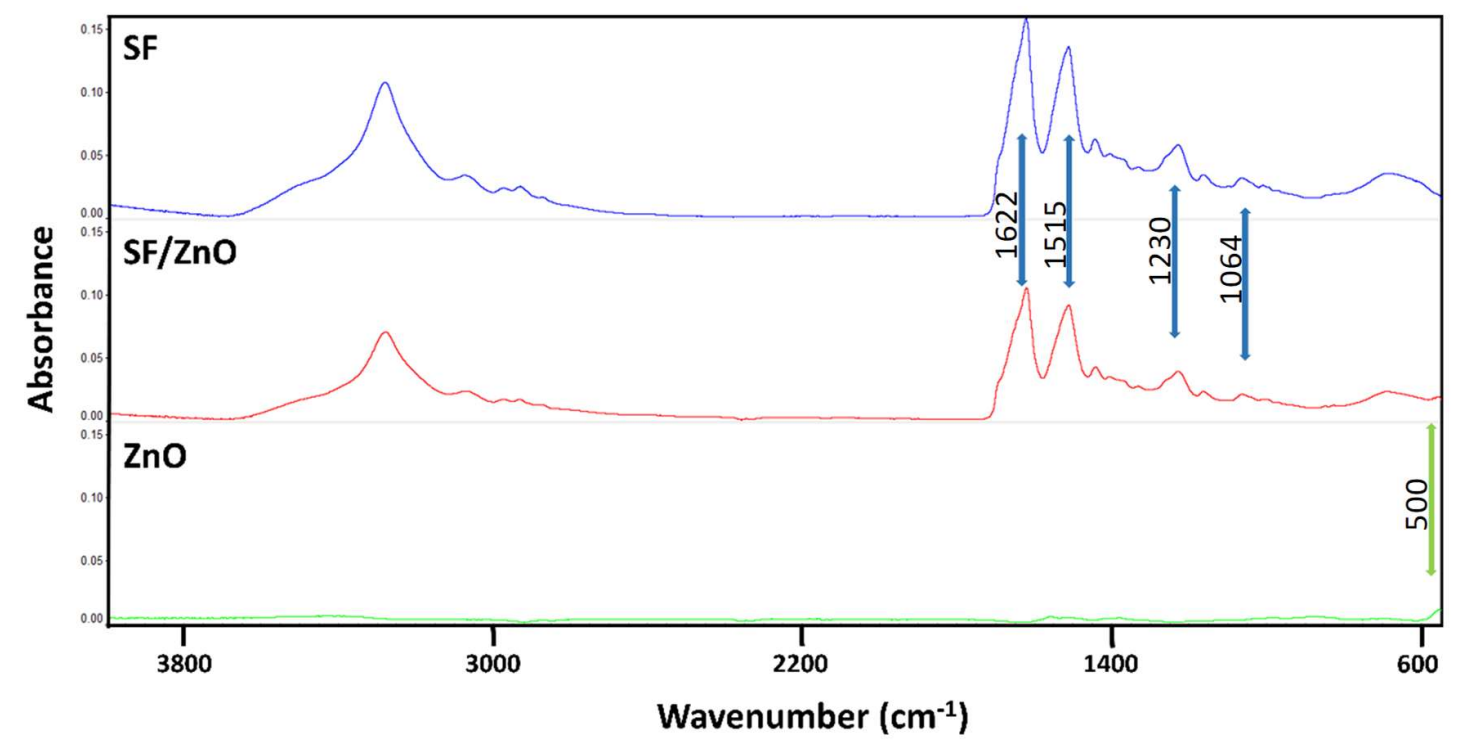

Figure 4. Infrared spectra of pure fibroin electrospun meshes (SF), fibroin mats containing $\mathrm{ZnO}$ nanoparticles $(\mathrm{SF} / \mathrm{ZnO})$ and pure $\mathrm{ZnO}$ nanoparticles $(\mathrm{ZnO})$. 
The results of ATR-FTIR analysis also confirmed that the $\mathrm{TiO}_{2}$ and $\mathrm{ZnO}$ nanoparticles were successfully incorporated in the materials. Along the spectra obtained from the $\mathrm{SF} / \mathrm{TiO}_{2}$ [39] and $\mathrm{SF} / \mathrm{ZnO}$ mats (Figure 5) are observed both, the characteristic bands of SF (previously described) and the corresponding to $\mathrm{TiO}_{2}$ or $\mathrm{ZnO}$. In the case of $\mathrm{SF} / \mathrm{TiO}_{2}$ mats it can be observed a broad band at $700 \mathrm{~cm}^{-1}$ that can be allocated to the existence of $\mathrm{TiO}_{2}$; this band is also present in the spectrum of pure $\mathrm{TiO}_{2}$ nanoparticles, and is caused by the vibrations of (Ti-O-Ti) stretch [23,45]. SF/ZnO meshes displayed a spectrum almost identical to that of pure SF mats caused by the intense peaks of fibroin, these ones masked the presence of $\mathrm{ZnO}$ nanoparticles, which peaks presented a lower intensity. However, a slight difference can be observed at $500 \mathrm{~cm}^{-1}$ (Figure 4, green arrow), a band present in both $\mathrm{SF} / \mathrm{ZnO}$ mats and $\mathrm{ZnO}$ nanoparticles, that can be attributed to the $\mathrm{ZnO}$ stretching modes, as stated by other authors $[46,47]$.

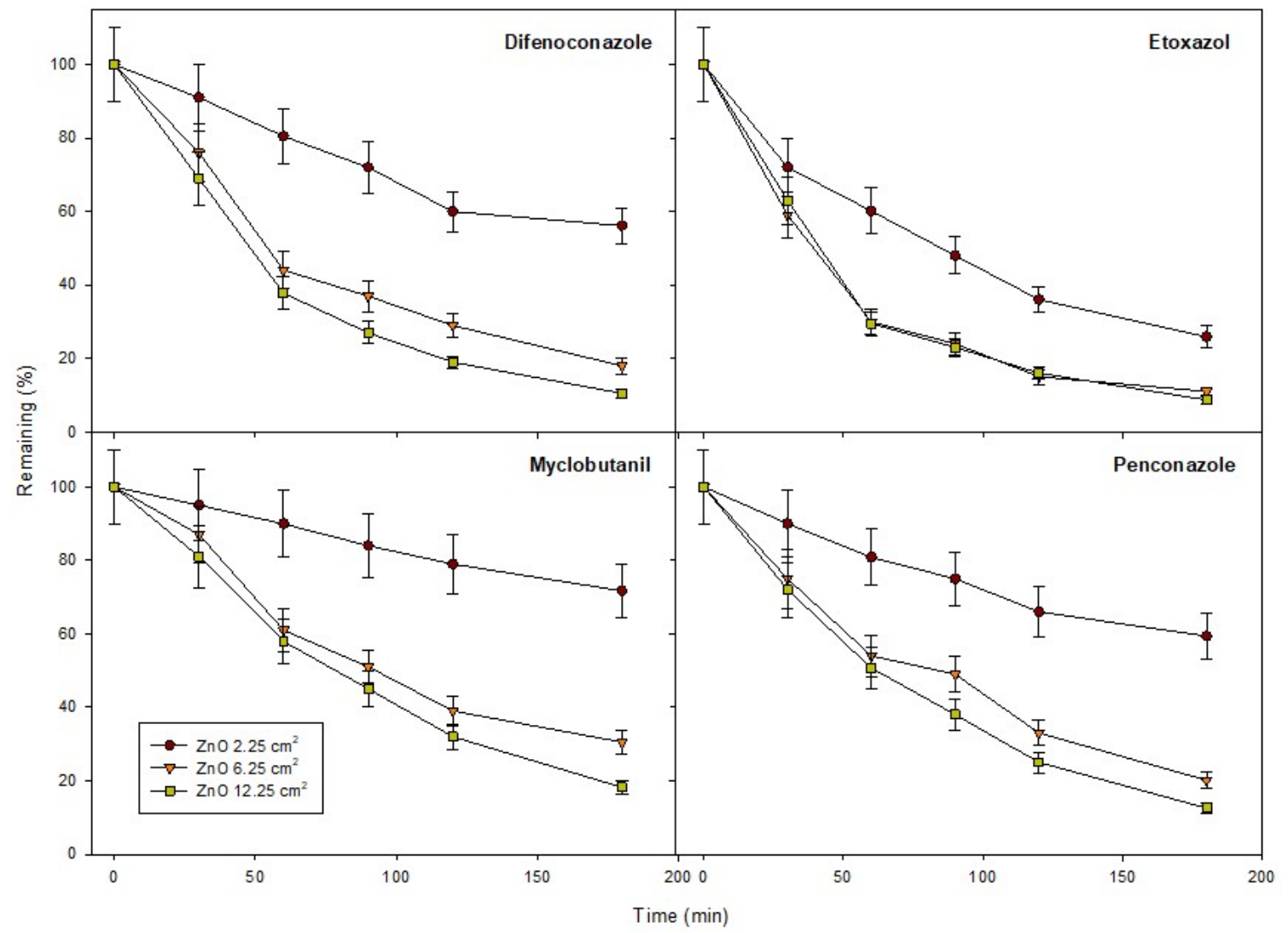

Figure 5. Optimization of $\mathrm{ZnO}$ load for photocatalytic degradation of the pesticides $\left(0.1 \mathrm{mg} \mathrm{L}^{-1}\right)$. Error bars denote standard deviation $(n=3)$.

\subsection{Mechanical Properties and Fibre Diameters}

The analysis of mechanical properties and diameter of the fibers of the materials obtained was performed in order to visualize the way in which these parameters could be affected by the deposition of either $\mathrm{TiO}_{2}$ or $\mathrm{ZnO}$ on the surface of the SF fibers.

As observed in Table 1 the mechanical properties of the different materials produced were not significantly affected by the covering of the fibers with the studied nanoparticles (ANOVA, $p>0.05$ ). The results obtained for tensile strength (0.3-0.4 MPa), elastic modulus (21-24 MPa), and strain at break (1.9-2.3\%) were in the range of the values described in previous studies using electrospun SF materials as scaffolds with different purposes $[28,31,32,48,49]$. However, the deposition of $\mathrm{TiO}_{2}$ gave rise to a homogeneous layer on the surface of the fibers that was responsible of a significant increase ( $p$ $<0.05)$ in the diameter of the fibers. This one was estimated around $2.8-2.9 \mu \mathrm{m}$ for SF and SF/ZnO mats but in the case of $\mathrm{SF} / \mathrm{TiO}_{2}$ meshes was $3.9 \mu \mathrm{m}$. 
Table 1. Average values of fiber diameter and mechanical properties studied in $\mathrm{SF} / \mathrm{ZnO}$ electrospun materials.

\begin{tabular}{ccccc}
\hline Mats & $\begin{array}{c}\text { Fiber Diameter } \\
(\mathbf{n m})\end{array}$ & $\begin{array}{c}\text { Tensile Strength } \\
\mathbf{( M P a )}\end{array}$ & $\begin{array}{c}\text { Elastic Modulus } \\
\mathbf{( M P a})\end{array}$ & Strain at Break (\%) \\
\hline $\mathbf{S F}$ & $2948 \pm 748$ & $0.41 \pm 0.12$ & $24.24 \pm 8.13$ & $2.28 \pm 0.26$ \\
$\mathrm{SF} / \mathrm{ZnO}$ & $2766 \pm 599$ & $0.32 \pm 0.10$ & $20.77 \pm 10.21$ & $2.27 \pm 0.41$ \\
$\mathrm{SF} / \mathrm{TiO}_{2}$ & $3858 \pm 1167^{*}$ & $0.33 \pm 0.09$ & $22.77 \pm 5.06$ & $1.85 \pm 0.27$ \\
\hline
\end{tabular}

${ }^{*}$ statistically different values compared to negative control $(p<0.05)$. Values of $\mathrm{SF}$ and $\mathrm{SF} / \mathrm{TiO}_{2}$ reported in Aznar-Cervantes et al. [40].

\subsection{Photocatalytic Activity and Kinetics}

The influence of $\mathrm{ZnO}$ loading on the elimination of the pesticides was assessed to gain knowledge on degradation efficiency. The essay was conducted with three fragments of SF/ZnO mats $(2.25,6.25$, and $12.25 \mathrm{~cm}^{2}$ ) coated with different $\mathrm{ZnO}$ amounts $(10,25$, and $50 \mathrm{mg}$, respectively). We noticed a significant increment in degradation rates when $\mathrm{ZnO}$ was added. Given that we did not observe significant differences $(p<0.05)$ when $\mathrm{ZnO}$ loading was increased from 25 to $50 \mathrm{mg}$ for most of pesticides (Figure 5), SF mats with $25 \mathrm{mg}$ of $\mathrm{ZnO}$ was the option finally selected. The photocatalytic degradation of pesticides was also assessed using $\mathrm{SF} / \mathrm{ZnO}$ and $\mathrm{SF} / \mathrm{TiO}_{2}$ (Figure 6). In the experiment carried out in the presence of $\mathrm{SF} / \mathrm{ZnO}$, the residual levels of difenoconazole, etoxazole, myclobutanil, and penconazole, after 180 min of irradiation were $18,5,30.5$, and $20.1 \mu \mathrm{g} \mathrm{L}^{-1}$, respectively. For SF/TiO ${ }_{2}$, the residual levels once finished the experiment were $24.6,3,57.3$, and $43.8 \mu \mathrm{g} \mathrm{L}^{-1}$, respectively. The experiments performed in the absence of catalyst showed a clear decrease in the photodecomposition rate and only a reduction between $65-98 \%$ of the initial mass was accomplished for etoxazole and difenoconazole, respectively, after $180 \mathrm{~min}$ of light exposure.

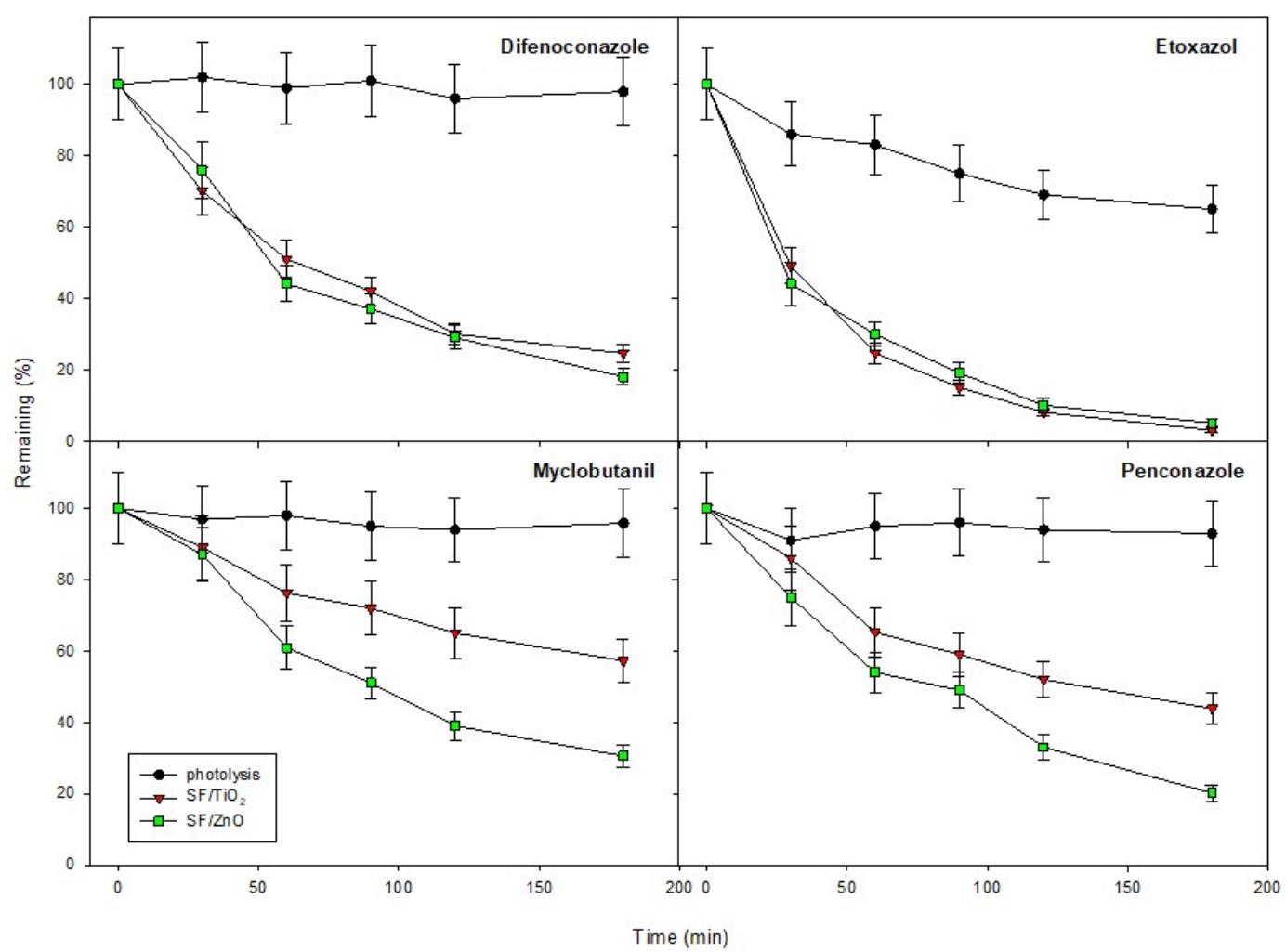

Figure 6. Pesticide decay $\left(0.1 \mathrm{mg} \mathrm{L}^{-1}\right)$ by photolysis and photocatalysis $\left(\mathrm{SF} / \mathrm{ZnO}\right.$ and $\left.\mathrm{SF} / \mathrm{TiO}_{2}\right)$ during the photoperiod. Approximately $250 \mathrm{mg} \mathrm{L}^{-1}$ of $\mathrm{ZnO}$ or $\mathrm{TiO}_{2}$ in all cases. Error bars denote standard deviation $(n=3)$. 
Regarding the efficiency for catalyzing the elimination of the pesticides studied, the comparison of electrospun SF materials (coated with similar amount of $\mathrm{TiO}_{2}$ and $\mathrm{ZnO}$ ) showed that both catalysts were equally efficient for removing etoxazole while in the case of difenoconazole, myclobutanil, and penconazole, $\mathrm{ZnO}$ was slightly more efficient.

The adsorption in dark conditions after $30 \mathrm{~min}$ of incubation was insignificant $(\sim 4.6 \%)$ for the studied pesticides on both $\mathrm{SF} / \mathrm{TiO}_{2}$ and $\mathrm{SF} / \mathrm{ZnO}$ mats. The higher values found for $\mathrm{SF} / \mathrm{TiO}_{2}$ (3.3-4.6\%) with respect to $\mathrm{SF} / \mathrm{ZnO}(1.2-2.6 \%)$ could be justified by the higher surface area of $\mathrm{SF} / \mathrm{TiO}_{2}$. The mineralization degree was assessed by measuring DOC content. The initial content of DOC was $4.7 \mathrm{mg} \mathrm{L}^{-1}$. The percentages found at the end of the solar treatment in the $\mathrm{SF} / \mathrm{TiO}_{2}$ and $\mathrm{SF} / \mathrm{ZnO}$ systems were $25.4 \%$ and $13.2 \%$, respectively. These lingering percentages could be attributed to the formation of recalcitrant intermediates during the experiment. In addition, coadjuvants presents in commercial products could also explain the values obtained.

Kinetic parameters of the photocatalytic degradation of pesticides for $\mathrm{SF} / \mathrm{TiO}_{2}$ and $\mathrm{SF} / \mathrm{ZnO}$ systems are listed in Table 2. Degradation followed a first-order behavior $\left(C_{P}=C_{P_{0}} e^{- \text {kapp }}{ }^{*}\right)$ with $\mathrm{R}^{2}$ ranging from 0.96 to 0.99 . The rate constants obtained for $\mathrm{SF} / \mathrm{TiO}_{2}$ and $\mathrm{SF} / \mathrm{ZnO}$ systems varied within $0.003-0.022 \mathrm{~min}^{-1}$ and $0.007-0.021 \mathrm{~min}^{-1}$, respectively.

Table 2. Kinetic parameters for photocatalytic treatments $\left(\mathrm{SF} / \mathrm{TiO} \mathrm{O}_{2}\right.$ and $\left.\mathrm{SF} / \mathrm{ZnO}\right)$ of pesticides in water under natural sunlight.

\begin{tabular}{ccccccc}
\hline \multirow{2}{*}{ Fungicide } & \multicolumn{3}{c}{$\mathbf{S F} / \mathrm{TiO}_{\mathbf{2}}$} & \multicolumn{3}{c}{$\mathrm{SF} / \mathbf{Z n O}$} \\
\cline { 2 - 7 } & $\mathbf{R}^{\mathbf{2}}$ & $\mathbf{k}\left(\mathbf{m i n}^{-\mathbf{1}}\right)$ & $\mathbf{t}_{\frac{1}{2}} \mathbf{( m i n )}$ & $\mathbf{R}^{\mathbf{2}}$ & $\mathbf{k}\left(\mathbf{m i n}^{-\mathbf{1}}\right)$ & $\mathbf{t}_{\frac{1}{2}}(\mathbf{m i n})$ \\
\hline Difenoconazole & 0.978 & $9.416 \times 10^{-3}$ & 73.6 & 0.979 & $1.092 \times 10^{-2}$ & 63.5 \\
Etoxazole & 0.998 & $2.258 \times 10^{-2}$ & 30.7 & 0.983 & $2.092 \times 10^{-2}$ & 33.1 \\
Myclobutanil & 0.974 & $3.276 \times 10^{-3}$ & 211.6 & 0.979 & $7.446 \times 10^{-3}$ & 93.1 \\
Penconazole & 0.962 & $5.183 \times 10^{-3}$ & 133.7 & 0.990 & $8.909 \times 10^{-3}$ & 77.8 \\
\hline
\end{tabular}

The higher photocatalytic activity of $\mathrm{SF} / \mathrm{ZnO}$ could be attributed to the fraction of solar spectrum that $\mathrm{ZnO}$ absorbs, since it is wider than the fraction absorbed by $\mathrm{TiO}_{2}$. Consequently, this system receives more light quanta [50,51]. In addition, other characteristics of the catalysts (surface area, crystallinity, particle size, optical properties, and impurities) would play an important role in the detected discrepancies between both systems [52]. Thus, a direct relation between the photocatalytic response of $\mathrm{ZnO}$ and the defects in its nanostructure can be established [13]. Furthermore, even though $\mathrm{SF} / \mathrm{ZnO}$ has major particle size $(\sim 200 \mathrm{~nm})$ and lower specific surface area $\left(\sim 21 \mathrm{~m}^{2} \mathrm{~g}^{-1}\right)$ than $\mathrm{SF} / \mathrm{TiO}_{2}$ $\left(\sim 20 \mathrm{~nm}\right.$ and $\left.31 \mathrm{~m}^{2} \mathrm{~g}^{-1}\right), \mathrm{ZnO}$ exhibits larger electronic mobility than $\mathrm{TiO}_{2}$ and therefore it shows a minor charge recombination [53]. In consequence, there is more unoccupied space for the absorption of pesticides, with the resulting enhancement of the photodegradation efficacy. The photodissolution for both, Ti and Zn into solution was observed to be inappreciable.

One crucial aspect that must be taken into account when using photocatalysts in practical industrial applications is their reusability. $\mathrm{SF} / \mathrm{TiO}_{2}$ and $\mathrm{SF} / \mathrm{ZnO}$ mats were recycled for another three times by simple washing and drying. After using them under same experimental conditions, we observed a slight reduction in the rate constants for pesticide degradation during the second, third, and fourth cycle ranged between $5 \%$ (3.6\% for $\mathrm{SF} / \mathrm{TiO}_{2}$ and $4.7 \%$ for $\mathrm{SF} / \mathrm{ZnO}$ ), $8 \%\left(5.9 \%\right.$ for $\mathrm{SF} / \mathrm{TiO}_{2}$ and $7.8 \%$ for $\mathrm{SF} / \mathrm{ZnO})$, and $12 \%\left(8.3 \%\right.$ for $\mathrm{SF} / \mathrm{TiO}_{2}$ and $11.5 \%$ for $\left.\mathrm{SF} / \mathrm{ZnO}\right)$, respectively.

\section{Materials and Methods}

\subsection{Pesticides and Reagents}

Pure standards (purity > 99\%) were supplied by Ehrenstorfer GmBh (Augsburg, Germany). The physicochemical properties of the pesticides are listed in Table 3 [54]. The commercial formulations (Score 25\% w/v—difenoconazole, Borneo 11\% w/v—etoxazole, and Systhane Forte 24\% 
$w / v$-myclobutanil and Furabel 10\% w/v-penconazole) were supplied by Syngenta Agro, Kenogard, Dow Agrosciences Iberica, S.A. and Probelte, respectively. Catalyzers, zinc oxide $(99.99 \%, 200 \mathrm{~nm}$, BET $\left.10 \mathrm{~m}^{2} \mathrm{~g}^{-1}\right)$ and titanium dioxide P25 $\left(99.5 \%,<21 \mathrm{~nm}, 50 \mathrm{~m}^{2} \mathrm{~g}^{-1}\right)$ were purchased from Alfa-Aesar (Karlsruhe, Germany) and Nippon Aerosil Co Ltd. (Osaka, Japan), respectively. Deionized water was obtained from a Millipore Water Purification System (Bedford, MA, USA).

Table 3. Physical-chemical characteristics of the pesticides used in this study.

\begin{tabular}{|c|c|c|c|c|c|c|c|}
\hline Compound & Structure & $\mathrm{MF}^{\mathrm{a}}$ & $\mathrm{MW}^{\mathrm{b}}$ & $\log K_{\text {OW }}{ }^{c}$ & $V P^{d}$ & WS $^{\mathrm{e}}$ & GUS $^{f}$ \\
\hline Difenoconazole & & $\mathrm{C}_{19} \mathrm{H}_{17} \mathrm{Cl}_{2} \mathrm{~N}_{3} \mathrm{O}_{3}$ & 406.3 & 4.36 & $\begin{array}{l}3.3 \times \\
10^{-5}\end{array}$ & 15.0 & 0.90 \\
\hline Etoxazole & & $\mathrm{C}_{21} \mathrm{H}_{23} \mathrm{FNO}_{2}$ & 359.4 & 5.52 & 0.007 & 0.07 & 0.25 \\
\hline Myclobutanil & & $\mathrm{C}_{15} \mathrm{H}_{17} \mathrm{ClN}_{4}$ & 288.8 & 2.89 & 0.198 & 132 & 3.30 \\
\hline Penconazole & & $\mathrm{C}_{13} \mathrm{H}_{15} \mathrm{Cl}_{2} \mathrm{~N}_{3}$ & 284.2 & 3.72 & 0.366 & 73.0 & 1.36 \\
\hline
\end{tabular}

${ }^{a}$ Molecular formula; ${ }^{b}$ Molecular mass $\left(\mathrm{g} \mathrm{mol}^{-1}\right) ;{ }^{\mathrm{c}}$ octanol/water partition coefficient $\left(\mathrm{K}_{\mathrm{OW}}\right){ }^{\mathrm{d}}$ Vapor pressure $(\mathrm{mPa}$ at $\left.25^{\circ} \mathrm{C}\right) ;{ }^{\text {e }}$ water solubility $\left(\mathrm{mg} \mathrm{L}^{-1}\right) ;{ }^{\mathrm{f}}$ GUS (Groundwater Ubiquity Score) index.

\subsection{Silk Fibroin Processing}

Cocoons of $B$. mori were chopped into four pieces and subsequently boiled in $0.02 \mathrm{M} \mathrm{Na}_{2} \mathrm{CO}_{3}$ during $30 \mathrm{~min}$, in order to accomplish the elimination of the sericin. Later, the SF was washed with water and dried during 3 days at $22 \pm 1^{\circ} \mathrm{C}$. It was dissolved using 9.3 $\mathrm{M} \mathrm{LiBr}$ (Acros Organics, Belgium) for $3 \mathrm{~h}\left(60^{\circ} \mathrm{C}\right)$, obtaining a $20 \mathrm{wt} . \%$ dissolution that was dialyzed with water for 3 days using Snakeskin Dialysis Tubing 3.5 KDa MWCO (Thermo Scientific, Waltham, MA, USA) carrying out eight changes of water $\left(4^{\circ} \mathrm{C}\right)$. The resultant $7 \mathrm{wt} . \% \mathrm{SF}$ dissolution was retrieved and concentrated by means of dialysis in $30 \mathrm{wt} . \%$ polyethylene glycol (11,000 Da) for $24 \mathrm{~h}$, in order to reach a concentration of $20-21 \mathrm{wt} . \%$ of $\mathrm{SF}$, which is optimal for the electrospinning experiments.

\subsection{Electrospinning and Post-Treatment of $\mathrm{SF} / \mathrm{TiO}{ }_{2}$ and $\mathrm{SF} / \mathrm{ZnO}$ Mats}

The electrospinning setup used in order to produce the materials was the same described in previous works of our research group $[28,32,37,48]$. The working conditions were adapted so that the Taylor cone was stable, being the voltage implemented to the capillary needle $19 \mathrm{kV}$ and $-1.5 \mathrm{kV}$ to the metallic collector $\left(\sim 375 \mathrm{~cm}^{2}\right)$. The distance between both elements of the setup was $42 \mathrm{~cm}$ and the selected injection rate of the SF dissolution was $1 \mathrm{~mL} \mathrm{~h}^{-1}$. Either $\mathrm{ZnO}$ or $\mathrm{TiO}_{2}$ nanoparticles (contained in methanol) were sprayed, using an atomizer, throughout the electrospinning experiments over the surface of the mats, as it is clarified below. Each mat was produced from $6 \mathrm{~mL}$ of $20 \% \mathrm{wt} \mathrm{SF}$ dissolution. Total of $30 \mathrm{~mL}$ of methanol containing $1.5 \mathrm{~g}$ of either $\mathrm{TiO}_{2}$ or $\mathrm{ZnO}$ nanoparticles were sprayed during the electrospinning experiments. With this purpose, seven rounds of atomization (periodically distributed) were carried out (4.3 mL per round), covering homogeneously the collector.

A total of $1.5 \mathrm{~mL}$ of SF dissolution was electrospun before the first atomization and after the last one, in order to guarantee the fabrication of a compact net, avoiding the loss of the nanoparticles 
included. Pure SF electrospun mats were produced as negative controls and the materials including $\mathrm{TiO}_{2}$ or $\mathrm{ZnO}$ in their composition were named as $\mathrm{SF} / \mathrm{TiO}{ }_{2}$ or $\mathrm{SF} / \mathrm{ZnO}$, respectively.

The annealing of all the materials produced was performed by an immersion step in absolute methanol during $30 \mathrm{~min}$, subsequently the mats were dried locating them between two portions of filter paper.

\section{4. $X R D, F E S E M, X P S, X D S$ and $S_{B E T}$}

XRD, FESEM, XPS, and XDS were used to characterize the materials as previously published by Garrido et al. [20]. A Quadrasorb SI-MP (Quantachrome Instruments, Boynton Beach, FL, USA) was used to obtain the gas sorption (nitrogen, $77 \mathrm{~K}$ ) surface area according to Brunauer-Emmett-Teller (BET) method. Outgassing was performed with a Masterprep Degasser (Quantachrome Instruments) at $120^{\circ} \mathrm{C}$ for $12 \mathrm{~h}$ for $\mathrm{SF} / \mathrm{ZnO}$.

\subsection{ATR-FTIR}

ATR-FTIR was the technique used to confirm the structural changes of SF from a water soluble conformation to a non-soluble state, with a characteristic increase in $\beta$-sheet content. IR spectra were also used to visualize the presence of the nanoparticles in the materials, by means of the analysis of some characteristic bands of $\mathrm{ZnO}$ or $\mathrm{TiO}_{2}$. For these purposes, a Nicolet iS5 spectrometer equipped with an iD5 ATR accessory (Thermo Scientific, USA) was used. The instrument worked in absorbance mode (resolution of $4 \mathrm{~cm}^{-1}$, a spectral range of $4000-550 \mathrm{~cm}^{-1}$, and 64 scans).

\subsection{Analysis of Mechanical Properties and Fibre Diameter}

Tensile tests were conducted using a universal test frame machine (Qtest; MTS Systems, Eden Prairie, MN, USA). Fragments of mats $(10 \mathrm{~mm} \times 30 \mathrm{~mm})$ were proven at a crosshead speed of $0.1 \mathrm{~mm} \cdot \mathrm{s}^{-1}$ with a load cell of $10 \mathrm{~N}$. A digital micrometer (Mitutoyo, IL, USA) with 0-25 mm, resolution of 0.001 $\mathrm{mm}$, and precision of $\pm 2 \mu \mathrm{m}$ was used to measure the width of each sample. The stress-strain curves obtained were used in order to calculate the tensile strength (MPa), the strain at break (\%) and the elastic modulus (MPa) in the linear elastic part of the curves. The tests were replicated three times per condition. Micrographs obtained by SEM were acquired and used to measure the diameter of the fibers of the materials produced.

\subsection{Photoreaction Setup}

Photocatalytic and photolytic trials were performed during August 2018 following the procedure described by Fenoll et al. with some modification [38]. For both experiments we mixed Milli-RX water ( $\mathrm{pH}$ 7.1, ORP $230 \mathrm{mV}$, conductivity $5.5 \mu \mathrm{S} \mathrm{cm}{ }^{-1}$, and TOC $<30 \mu \mathrm{g} \mathrm{L}{ }^{-1}$ ) with commercial formulations of the pesticides studied. Experiments were performed in vessels containing $100 \mathrm{~mL}$ of water and introducing a square fragment of $\mathrm{SF} / \mathrm{semiconductor}$ oxide mats. The vessels were exposed to sunlight for $180 \mathrm{~min}$ (from 11 AM to 2 PM). Before starting experiments, the solution was stirred for $30 \mathrm{~min}$ in darkness and later a sample was collected to measure the adsorption of the pesticides onto each square fragment of $\mathrm{SF} / \mathrm{ZnO}$ mats. Figure 7 illustrates a schematic picture of the experimental setup. $948.6 \pm 52.4,21.5 \pm 2.3$, and $1.7 \pm 0.4\left(\right.$ all in $\mathrm{W} \mathrm{m}^{-2}$ ) of VIS plus NIR, UVA, and UVB, respectively, were recorded at noon. 


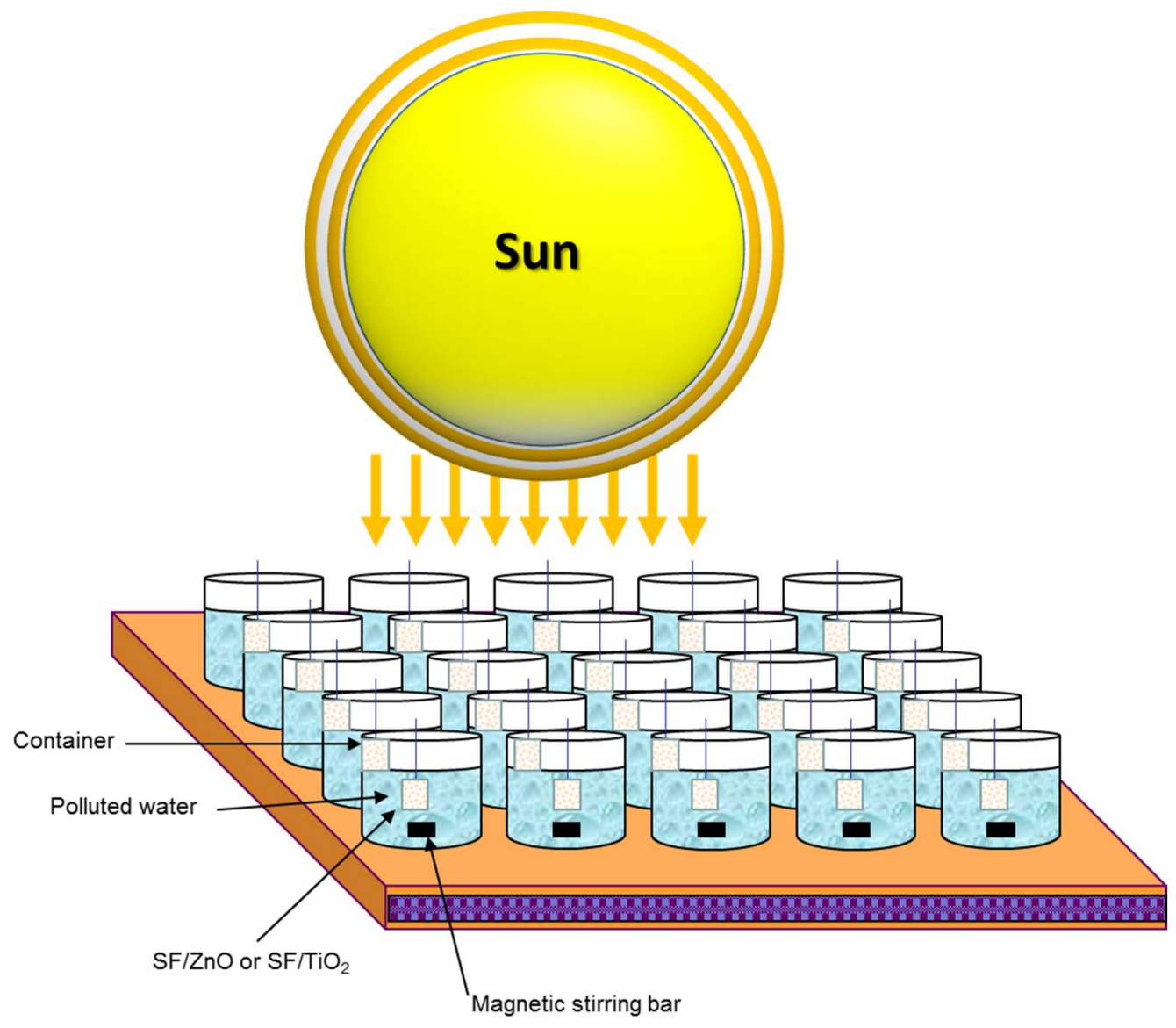

Figure 7. Schematic drawing of the experimental setup.

\subsection{Analytical Determinations}

Pesticide residues in water samples were analyzed by an HPLC system (Agilent Series 1200 Agilent Technologies, Santa Clara, CA, USA) and a G6410A triple quadrupole mass spectrometer provided with an $\mathrm{ESI}^{+}$interface following the methodology previously published by Fenoll et al. [55]. Table 4 shows the analytical conditions of the studied pesticides. The presence of Ti and $\mathrm{Zn}$ in solution was determined using an Agilent $7900 \mathrm{ICP} / \mathrm{MS}$ system. The measure of dissolved organic carbon (DOC) content in water samples was performed by a Multi N/C 3100 TOC Analyzer (Analytic Jena AG, Jena, Germany) equipped with an NDIR detector $\left(950^{\circ} \mathrm{C}\right)$, following the procedure outlined by Fenoll et al. [38].

Table 4. Analytical conditions of the studied pesticides.

\begin{tabular}{|c|c|c|c|c|c|c|c|}
\hline Compound & $t_{R}(\min )$ & $\mathrm{SRM}_{1}$ & $\begin{array}{c}\text { Fragmentor } 1 \\
\text { (V) }\end{array}$ & $\begin{array}{c}\text { Collision } \\
\text { Energy }_{1}(\mathrm{~V})\end{array}$ & $\mathrm{SRM}_{2}$ & $\begin{array}{c}\text { Fragmentor } \\
\text { (V) }\end{array}$ & $\begin{array}{c}\text { Collision } \\
\text { Energy }_{2}(V)\end{array}$ \\
\hline Difenoconazole & 28.10 & $406 \rightarrow 251$ & 130 & 20 & $406 \rightarrow 337$ & 130 & 15 \\
\hline Etoxazole & 32.90 & $360 \rightarrow 141$ & 120 & 30 & $360 \rightarrow 304$ & 120 & 20 \\
\hline Myclobutanil & 25.60 & $289 \rightarrow 70$ & 130 & 15 & $289 \rightarrow 125$ & 130 & 40 \\
\hline Penconazole & 26.90 & $284 \rightarrow 70$ & 110 & 30 & $284 \rightarrow 159$ & 110 & 10 \\
\hline
\end{tabular}

SRM: Selected Reaction Monitoring.

\subsection{Statistical Analysis}

Statistical analyses and curve fitting were performed by SigmaPlot version 13.0 statistical software (Systat, Software Inc., San Jose, CA, USA). IBM SPSS 25 statistics software was used to analyze statistics of mechanical properties and fiber diameter. ANOVA $(p<0.05)$ or Mann-Whitney $(p<0.05)$ tests 
were determined by the data accomplished normality and homogeneity of variance requirements or not, respectively.

\section{Conclusions}

One of the environmental issues that citizens and scientists are most concerned is the pollution of natural resources by pesticides residues. These substances are capable of polluting remote areas from the point where they were applied and remaining for years/decades. In this work, we have developed a new and simple method to obtain silk fibroin (SF) fibers coated with $\mathrm{ZnO}$ nanoparticles using electrospinning technique. $\mathrm{ZnO}$ nanostructures have been shown to be a potential candidate as photocatalyst for solar-driven photodegradation process of pesticides owing to its low production cost in comparison to $\mathrm{TiO}_{2}$, non-toxic, and ability to absorb larger fraction of solar spectrum compared to $\mathrm{TiO}_{2}$. The photocatalytic efficiency of these materials under natural sunlight exposure was studied on the removal of four pesticides in water. The results showed an increment in the degradation rates when the $\mathrm{ZnO}$ loading was increased. To promote the practical applicability of this methodology a study of reusability was carried out showing that the reduction in rate constants for photocatalytic degradation after four cycles was lower than $11 \%$. The photocatalytic efficiency of electrospun SF fibers coated with similar amount of $\mathrm{TiO}_{2}$ and $\mathrm{ZnO}$ was slightly higher in the case of $\mathrm{SF} / \mathrm{ZnO}$. Thus, the obtained nanocomposite $(\mathrm{SF} / \mathrm{ZnO})$ has been shown to be a potential candidate as photocatalyst for solar-driven photocatalytic degradation of pesticide residues to minimize their potential harm to the environment and human health. In order to provide more information on the photocatalytic degradation of pesticides in larger scale of application, future research should be developed using $\mathrm{SF} / \mathrm{ZnO}$ mats.

Author Contributions: Conceptualization, S.A.-C., J.L.C., S.N. and J.F.; methodology, I.G., M.A., N.V., M.J.Y.-G., S.N., and J.F.; validation, I.G., M.A., N.V., and M.J.Y-G.; formal analysis, S.A.-C., J.L.C., S.N., and J.F.; investigation, S.A.-C., J.L.C., S.N., and J.F.; resources, I.G., M.A., N.V., M.J.Y.-G., S.N., and J.F.; data curation, S.A.-C., S.N., and J.F.; writing-original draft preparation, I.G., S.A.-C., S.N., and J.F.; writing — review and editing, I.G., S.N., and J.F.; visualization, I.G., S.N., and J.F.; supervision, S.N. and J.F.; project administration, I.G.; funding acquisition, S.A.-C., J.L.C., S.N., and J.F. All authors have read and agreed to the published version of the manuscript and there are no other persons who satisfied the criteria for authorship but are not listed. We further confirm that all of us have approved the order of authors listed in the manuscript.

Funding: This work was financially supported by Operative Regional Program FEDER for Murcia 2014-2020, project RTA2015-00073-00-00, INIA 2017-2020 and with the aid of the Resolution of Presidency of State Research Agency (State Subprogram of Training of State Program of Promotion of Talent and its Employability), within the framework of the State Plan for Scientific and Technical Research and Innovation 2013-2016 co-funded by the European Social Fund. Salvador Aznar-Cervantes acknowledges the financial support of his research contract, program INIA-CCAA (DOC INIA 2015), announced by the National Institute for Agricultural and Food Research and Technology (INIA) and supported by The Spanish State Research Agency (AEI) under the Spanish Ministry of Economy, Industry and Competitiveness.

Acknowledgments: The authors are grateful to Herminia Jiménez, Inmaculada Garrido, Juana Cava, and María V. Molina for technical assistance.

Conflicts of Interest: The authors declare no conflict of interest associated with this manuscript.

\section{References}

1. Mnif, W.; Hassine, A.I.H.; Bouaziz, A.; Bartegi, A.; Thomas, O.; Roig, B. Effect of endocrine disruptor pesticides: A review. Int. J. Environ. Res. Public Health 2011, 8, 2265-2303. [CrossRef] [PubMed]

2. Vela, N.; Pérez-Lucas, G.; Fenoll, J.; Navarro, S. Recent overview on the abatement of pesticide residues in water by photocatalytic treatment using $\mathrm{TiO}_{2}$. In Applications of Titanium Dioxide; Janus, M., Ed.; IntechOpen: Rijeka, Croatia, 2017; pp. 147-177.

3. Ribeiro, A.R.; Nunes, O.C.; Pereira, M.F.R.; Silva, A.M.T. An overview on the advanced oxidation processes applied for the treatment of water pollutants defined in the recently launched Directive 2013/39/EU. Environ. Int. 2015, 75, 33-51. [CrossRef] [PubMed] 
4. Fagan, R.; McCormack, E.; Dionysiou, D.D.; Pillai, S.C. A review of solar and visible light active $\mathrm{TiO}_{2}$ photocatalysis for treating bacteria, cyanotoxins and contaminants of emerging concern. Mater. Sci. Semicond. Process. 2016, 42, 2-14. [CrossRef]

5. Miklos, D.B.; Remy, C.; Jekel, M.; Linden, K.G.; Drewes, J.E.; Hübner, U. Evaluation of advanced oxidation processes for water and wastewater treatment. A critical review. Water Res. 2018, 139, 118-131. [CrossRef] [PubMed]

6. Quiroz, M.A.; Bandala, E.R.; Martínez-Huitle, C.A. Advanced Oxidation Processes (AOPs) for Removal of Pesticides from Aqueous Media. In Pesticides-Formulations, Effects, Fate; Stoytcheva, M., Ed.; IntechOpen: Rijeka, Croatia, 2011; pp. 685-730.

7. Chen, X.; Wu, Z.; Liu, D.; Gao, Z. Preparation of ZnO photocatalyst for the efficient and rapid photocatalytic degradation of azo dyes. Nanoscale Res. Lett. 2017, 12, 4-13. [CrossRef] [PubMed]

8. Bhatia, S.; Verma, N. Photocatalytic activity of ZnO nanoparticles with optimization of defects. Mater. Res. Bull. 2017, 95, 468-476. [CrossRef]

9. Wu, M.C.; Chan, S.H.; Lin, T.H. Fabrication and photocatalytic performance of electrospun PVA/silk/TiO 2 nanocomposite textile. Funct. Mater. Lett. 2015, 8, 1540013. [CrossRef]

10. Nakata, K.; Fujishima, A. $\mathrm{TiO}_{2}$ photocatalysis: Design and applications. J. Photochem. Photobiol. C Photochem. Rev. 2012, 13, 169-189. [CrossRef]

11. Ong, C.B.; Ng, L.Y.; Mohammad, A.W. A review of ZnO nanoparticles as solar photocatalysts: Synthesis, mechanisms and applications. Renew. Sustain. Energy Rev. 2018, 81, 536-551. [CrossRef]

12. Wetchakun, K.; Wetchakun, N.; Sakulsermsuk, S. An overview of solar/visible light-driven heterogeneous photocatalysis for water purification: $\mathrm{TiO}_{2}$ and $\mathrm{ZnO}$ based photocatalysts used in suspension photoreactors. J. Ind. Eng. Chem. 2019, 71, 19-49. [CrossRef]

13. Montero-Muñoz, M.; Ramos-Ibarra, J.E.; Rodríguez-Páez, J.E.; Teodoro, M.D.; Marques, G.E.; Sanabria, A.E.; Cajas, P.C.; Páez, C.A.; Heinrichs, B.; Coaquira, J.A.H. Role of defects on the enhancement of the photocatalytic response of ZnO nanostructures. Appl. Surf. Sci. 2018, 448, 646-654. [CrossRef]

14. Wei, G.; Zuo, H.F.; Guo, Y.R.; Pan, Q.J. Synthesis of ZnO with enhanced photocatalytic activity: A novel approach using nanocellulose. BioResources 2016, 11, 6244-6253. [CrossRef]

15. Xu, J.; Su, H.; Han, J.; Chen, Y.; Song, W.; Gu, Y.; Moon, W.J.; Zhang, D. In situ deposition of flower-like ZnO on silk fibroin fibers. Appl. Phys. A 2012, 108, 235-238. [CrossRef]

16. Zhao, G.; Zhang, Y.; Zhang, L.; Ye, Z.G.; Ren, W.; Xu, F.; Wang, S.; Liu, M.; Zhang, X. 3D Conformal modification of electrospun silk nanofibers with nanoscaled $\mathrm{ZnO}$ deposition for enhanced photocatalytic activity. ACS Biomater. Sci. Eng. 2017, 3, 2900-2906. [CrossRef]

17. Etacheri, V.; Di Valentin, C.; Schneider, J.; Bahnemann, D.; Pillai, S.C. Visible-light activation of $\mathrm{TiO}_{2}$ photocatalysts: Advances in theory and experiments. J. Photochem. Photobiol. C Photochem. Rev. 2015, 25, 1-29. [CrossRef]

18. Ahmed, S.; Rasul, M.G.; Brown, R.; Hashib, M.A. Influence of parameters on the heterogeneous photocatalytic degradation of pesticides and phenolic contaminants in wastewater: A short review. J. Environ. Manag. 2011, 92, 311-330. [CrossRef] [PubMed]

19. Fenoll, J.; Garrido, I.; Cava, J.; Hellín, P.; Flores, P.; Navarro, S. Photometabolic pathways of chlorantraniliprole in aqueous slurries containing binary and ternary oxides of $\mathrm{Zn}$ and Ti. Chem. Eng. J. 2015, 264, $720-727$. [CrossRef]

20. Garrido, I.; Pastor-Belda, M.; Campillo, N.; Viñas, P.; Yañez, M.J.; Vela, N.; Navarro, S.; Fenoll, J. Photooxidation of insecticide residues by $\mathrm{ZnO}$ and $\mathrm{TiO}_{2}$ coated magnetic nanoparticles under natural sunlight. J. Photochem. Photobiol. A Chem. 2019, 372, 245-253. [CrossRef]

21. Cai, L.; Shao, H.; Hu, X.; Zhang, Y. Reinforced and ultraviolet resistant silks from silkworms fed with titanium dioxide nanoparticles. ACS Sustain. Chem. Eng. 2015, 3, 2551-2557. [CrossRef]

22. Feng, X.X.; Zhang, L.L.; Chen, J.Y.; Guo, Y.H.; Zhang, H.P.; Jia, C.I. Preparation and characterization of novel nanocomposite films formed from silk fibroin and nano-TiO 2 . Int. J. Biol. Macromol. 2007, 40, $105-111$. [CrossRef]

23. Kim, J.H.; Sheikh, F.A.; Ju, H.W.; Park, H.J.; Moon, B.M.; Lee, O.J.; Park, C.H. 3D silk fibroin scaffold incorporating titanium dioxide $\left(\mathrm{TiO}_{2}\right)$ nanoparticle (NPs) for tissue engineering. Int. J. Biol. Macromol. 2014, 68, 158-168. [CrossRef] [PubMed] 
24. Jao, W.C.; Yang, M.C.; Lin, C.H.; Hsu, C.C. Fabrication and characterization of electrospun silk fibroin/TiO 2 nanofibrous mats for wound dressings. Polym. Adv. Technol. 2012, 23, 1066-1076. [CrossRef]

25. Li, C.; Vepari, C.; Jin, H.J.; Kim, H.J.; Kaplan, D.L. Electrospun silk-BMP-2 scaffolds for bone tissue engineering. Biomaterials 2006, 27, 3115-3124. [CrossRef] [PubMed]

26. Wang, J.; Sun, B.; Bhutto, M.A.; Zhu, T.; Yu, K.; Bao, J.; Morsi, Y.; El-Hamshary, H.; El-Newehy, M.; Mo, X. Fabrication and characterization of Antheraea pernyi silk fibroin-blended P(LLA-CL) nanofibrous scaffolds for peripheral nerve tissue engineering. Front. Mater. Sci. 2017, 11, 22-32. [CrossRef]

27. Aznar-Cervantes, S.; Roca, M.I.; Martinez, J.G.; Meseguer-Olmo, L.; Cenis, J.L.; Moraleda, J.M.; Otero, T.F. Fabrication of conductive electrospun silk fibroin scaffolds by coating with polypyrrole for biomedical applications. Bioelectrochemistry 2012, 85, 36-43. [CrossRef] [PubMed]

28. Aznar-Cervantes, S.; Pagán, A.; Martínez, J.G.; Bernabeu-Esclapez, A.; Otero, T.F.; Meseguer-Olmo, L.; Paredes, J.I.; Cenis, J.L. Electrospun silk fibroin scaffolds coated with reduced graphene promote neurite outgrowth of PC-12 cells under electrical stimulation. Mater. Sci. Eng. C 2017, 79, 315-325. [CrossRef]

29. Martinez, J.G.; Aznar-Cervantes, S.; Abel Lozano-Pérez, A.; Cenis, J.L.; Otero, T.F. Graphene adsorbed on silk-fibroin meshes: Biomimetic and reversible conformational movements driven by reactions. Electrochim. Acta 2016, 209, 521-528. [CrossRef]

30. Zhang, X.; Reagan, M.R.; Kaplan, D.L. Electrospun silk biomaterial scaffolds for regenerative medicine. Adv. Drug Deliv. Rev. 2009, 61, 988-1006. [CrossRef]

31. Aznar-Cervantes, S.D.; Vicente-Cervantes, D.; Meseguer-Olmo, L.; Cenis, J.L.; Lozano-Pérez, A.A. Influence of the protocol used for fibroin extraction on the mechanical properties and fiber sizes of electrospun silk mats. Mater. Sci. Eng. C 2013, 33, 1945-1950. [CrossRef]

32. Aznar-Cervantes, S.D.; Lozano-Pérez, A.A.; García Montalban, M.; Villora, G.; Vicente-Cervantes, D.; Cenis, J.L. Importance of refrigeration time in the electrospinning of silk fibroin aqueous solutions. J. Mater. Sci. 2015, 50, 4879-4887. [CrossRef]

33. Kearns, V.; MacIntosh, A.C.; Crawford, A.; Hatton, P.V. Silk-based biomaterials for tissue engineering. Top. Tissue Eng. 2008, 4, 1-19.

34. Du, G.Y.; He, S.W.; Sun, C.X.; Mi, L.D. Bone morphogenic protein-2 (rhBMP2)-loaded silk fibroin scaffolds to enhance the osteoinductivity in bone tissue engineering. Nanoscale Res. Lett. 2017, 12, 573. [CrossRef] [PubMed]

35. Sahoo, S.; Toh, S.L.; Goh, J.C.H. A bFGF-releasing silk/PLGA-based biohybrid scaffold for ligament/tendon tissue engineering using mesenchymal progenitor cells. Biomaterials 2010, 31, 2990-2998. [CrossRef] [PubMed]

36. Nalvuran, H.; Elçin, A.E.; Elçin, Y.M. Nanofibrous silk fibroin/reduced graphene oxide scaffolds for tissue engineering and cell culture applications. Int. J. Biol. Macromol. 2018, 114, 77-84. [CrossRef]

37. López-Maya, E.; Montoro, C.; Rodríguez-Albelo, L.M.; Aznar Cervantes, S.D.; Lozano-Pérez, A.A.; Cenís, J.L.; Barea, E.; Navarro, J.A.R. Textile/metal-Organic-framework composites as self-detoxifying filters for chemical-warfare agents. Angew. Chem. Int. Ed. 2015, 54, 6790-6794. [CrossRef]

38. Fenoll, J.; Garrido, I.; Pastor-Belda, M.; Camillo, N.; Viñas, P.; Yáñez, M.J.; Vela, N.; Navarro, S. Solar detoxification of water polluted with fungicide residues using $\mathrm{ZnO}$ coated magnetic particles. Chem. Eng. J. 2017, 330, 71-81. [CrossRef]

39. Aznar-Cervantes, S.; Aliste, M.; Garrido, I.; Yáñez-Gascón, M.J.; Vela, N.; Cenis, J.L.; Navarro, S.; Fenoll, J. Electrospun silk fibroin/ $/ \mathrm{TiO}_{2}$ mats. Preparation, characterization and efficiency for the photocatalytic solar treatment of pesticide polluted water. RSC Adv. 2020, 10, 1917-1924. [CrossRef]

40. Naumkin, A.V.; Kraut-Vass, A.; Powell, C.J.; Gaarenstroom, S.W. NIST X-Ray Photoelectron Spectroscopy Database 20, Version 4.1. 2012. Available online: http://srdata.nist.gov/xps/ (accessed on 15 September 2019).

41. Ökte, A.N. Characterization and photocatalytic activity of Ln (La, Eu, Gd, Dy and Ho) loaded ZnO nanocatalysts. Appl. Catal. A Gen. 2014, 475, 27-39. [CrossRef]

42. Zhang, F.; Zuo, B.Q.; Bai, L. Study on the structure of SF fiber mats electrospun with HFIP and FA and cells behavior. J. Mater. Sci. 2009, 44, 5682-5687. [CrossRef]

43. Wang, M.; Jin, H.J.; Kaplan, D.L.; Rutledge, G.C. Mechanical Properties of Electrospun Silk Fibers. Macromolecules 2004, 37, 6856-6864. [CrossRef]

44. Wang, H.; Shao, H.; Hu, X. Structure of silk fibroin fibers made by an electrospinning process from a silk fibroin aqueous solution. J. Appl. Polym. Sci. 2006, 101, 961-968. [CrossRef] 
45. Ochoa, Y.; Ortegón, Y.; Vargas, M.; Rodríguez Páez, J.E. Síntesis de $\mathrm{TiO}_{2}$, fase anatasa, por el método Pechini. Suplemento de la Revista Latinoamericana de Metalurgia y Materiales 2009, 1, 931-937.

46. Senthilkumaar, S.; Rajendran, K.; Banerjee, S.; Chini, T.K.; Sengodan, V. Influence of Mn doping on the microstructure and optical property of ZnO. Mater. Sci. Semicond. Process. 2008, 11, 6-12. [CrossRef]

47. Djaja, N.F.; Montja, D.A.; Saleh, R. The effect of Co incorporation into ZnO nanoparticles. Adv. Mater. Phys. Chem. 2013, 3, 33-41. [CrossRef]

48. Millán-Rivero, J.E.; Martínez, C.M.; Romecín, P.A.; Aznar-Cervantes, S.D.; Carpes-Ruiz, M.; Cenis, J.L.; Moraleda, J.M.; Atucha, N.M.; García-Bernal, D. Silk fibroin scaffolds seeded with Wharton's jelly mesenchymal stem cells enhance re-epithelialization and reduce formation of scar tissue after cutaneous wound healing. Stem Cell Res. Ther. 2019, 6, 1-14. [CrossRef] [PubMed]

49. Aznar-Cervantes, S.; Martínez, J.G.; Bernabeu-Esclapez, A.; Lozano-Pérez, A.A.; Meseguer-Olmo, L.; Otero, T.F.; Cenis, J.L. Fabrication of electrospun silk fibroin scaffolds coated with graphene oxide and reduced graphene for applications in biomedicine. Bioelectrochemistry 2016, 108, 36-45. [CrossRef] [PubMed]

50. Malato, S.; Fernández-Ibañez, P.; Maldonado, M.I.; Blanco, J.; Gernjak, W. Decontamination and disinfection of water by solar photocatalysis: Recent overview and trends. Catal. Today 2009, 147, 1-59. [CrossRef]

51. Sakthivel, S.; Neppolian, B.; Shankar, M.V.; Arabindoo, B.; Palanichamy, M.; Murugesan, V. Solar photocatalytic degradation of azo dye: Comparison of photocatalytic efficiency of $\mathrm{ZnO}$ and $\mathrm{TiO}_{2}$. Sol. Energ Mater. Sol. Cells 2003, 77, 65-82. [CrossRef]

52. Salah, N.H.; Bouhelassa, M.; Bekkouche, S.; Boultif, A. Study of photocatalytic degradation of phenol. Desalination 2004, 166, 347-354. [CrossRef]

53. Kitsiou, V.; Filippidis, N.; Mantzavinos, D.; Pouios, I. Heterogeneous and homogeneous photocatalytic degradation of the insecticide imidacloprid in aqueous solutions. Appl. Catal. B Eviron. 2009, 86, 27-35. [CrossRef]

54. Lewis, K.A.; Tzilivakis, J.; Warner, D.J.; Green, A. An international database for pesticide risk assessments and management. Hum. Ecol. Risk Assess. Int. J. 2016, 22, 1050-1064. [CrossRef]

55. Fenoll, J.; Hellín, P.; Martínez, C.M.; Flores, P.; Navarro, S. Determination of 48 pesticides and their main metabolites in water samples by employing sonication and liquid chromatography-Tandem mass spectrometry. Talanta 2011, 85, 975-982. [CrossRef] [PubMed]

(C) 2020 by the authors. Licensee MDPI, Basel, Switzerland. This article is an open access article distributed under the terms and conditions of the Creative Commons Attribution (CC BY) license (http://creativecommons.org/licenses/by/4.0/). 